\title{
Potential Factors behind the Decline of Pinus pinea Nut Production in Mediterranean Pine Forests
}

\author{
Yara El Khoury ${ }^{1,2}$, Elise Noujeim ${ }^{1, *}$, Giovanni Bubici ${ }^{3}{ }^{(0)}$, Eustachio Tarasco ${ }^{2}$, , Charbel Al Khoury ${ }^{4}$ \\ and Nabil Nemer $5, *$ (1)
}

1 National Center for Marine Sciences, National Council for Scientific Research-CNRS, Ryad El Solh 1107 2260, 59, Zahia Selman Street, Beirut P.O. Box 11-8281, Lebanon; khouryaragro@gmail.com

2 Dipartimento di Scienze del Suolo, della Pianta e degli Alimenti (Di.S.S.P.A.), Università degli Studi di Bari "Aldo Moro", Via Amendola 165/A, 70126 Bari, Italy; eustachio.tarasco@uniba.it

3 Istituto per la Protezione Sostenibile delle Piante, Consiglio Nazionale delle Ricerche, Via Amendola 165/A, 70126 Bari, Italy; giovanni.bubici@ipsp.cnr.it

4 Department of Natural Sciences, School of Arts and Sciences, Lebanese American University, Campus, Byblos P.O. Box 36, Lebanon; charbel.alkhoury@lau.edu.lb

5 Department of Agriculture and Food Engineering, Holy Spirit University of Kaslik, Jounieh P.O. Box 446, Lebanon

* Correspondence: Enjeim@cnrs.edu.lb (E.N.); nabilnemer@usek.edu.lb (N.N.)

check for updates

Citation: El Khoury, Y.; Noujeim, E.; Bubici, G.; Tarasco, E.; Al Khoury, C.; Nemer, N. Potential Factors behind the Decline of Pinus pinea Nut Production in Mediterranean Pine Forests. Forests 2021, 12, 1167. https://doi.org/10.3390/f12091167

Academic Editor: Thomas J. Dean

Received: 8 July 2021

Accepted: 25 August 2021

Published: 28 August 2021

Publisher's Note: MDPI stays neutral with regard to jurisdictional claims in published maps and institutional affiliations.

Copyright: (C) 2021 by the authors. Licensee MDPI, Basel, Switzerland. This article is an open access article distributed under the terms and conditions of the Creative Commons Attribution (CC BY) license (https:// creativecommons.org/licenses/by/ $4.0 /)$.

\begin{abstract}
Mediterranean stone pine nut is appreciated for its high economic and nutritional value. Starting in 2012, Pinus pinea nut production declined throughout the Mediterranean area. The dry cone syndrome associated with this decline and the introduction of Leptoglossus occidentalis occurred simultaneously. This study aims to evaluate potential reasons behind the decline in pine nut production in Lebanon, considering climatic factors and the invasion of L. occidentalis. Correlation analysis was used to examine a potential relationship between cone yield and the percentage of damaged seeds per cone. Climatic variables were also tested. Two time periods were considered for analysis: before and after 2012. Cone production and the percentage of damaged seeds were negatively correlated $(\mathrm{r}=-0.42)$. From 2012 to 2017 , cone production declined by $50 \%$ and the percentage of damaged seeds increased on average from 3\% in 2012 up to $60 \%$ in 2017 . Correlations were detected between cone production and the temperature of the hottest three months of the year of harvesting, and between cone production and average temperatures during the year of cone initiation. A conjunction of factors that include L. occidentalis and climatic factors might have affected the pine nut production in Lebanon.
\end{abstract}

Keywords: Pinus pinea; pine nuts; Leptoglossus occidentalis; climate

\section{Introduction}

Distributed around the Mediterranean basin and coastal Portugal, stone pine (Pinus pinea L.) occupies a wide range of climatic and soil conditions. The tree is valued for its timber, resin and bark, and it protects soil against erosion in addition to its other environmental and aesthetic purposes [1]. However, since the Paleolithic era, its edible seeds have been the most economically important non-wood forest product (NWFP) obtained from Mediterranean forests [2,3]. Pine nuts are a high-value product in the region, with current retail prices exceeding $100 \mathrm{EUR} / \mathrm{kg}$ in Europe [4] and ranging between 35 and $55 \mathrm{EUR} / \mathrm{kg}$ (retail price) in Lebanon [5]. In some rain-fed areas (i.e., Mediterranean areas), harvesting pine nuts provides a much higher income in the short term than harvesting wood after long rotations [6,7]. However, Mediterranean pine forests are threatened by a drought-prone environment, difficult socioeconomic conditions and overexploitation, all of which affect $P$. pinea forest growth, health and pine nut production [8].

The cone development cycle of $P$. pinea requires at least three years, with the tree bearing its first-, second- and third-year cones at the same time [9]. Pollination of female 
cones occurs on the first-year cones, whereas fecundation occurs on the third-year cones before maturation and harvesting [10]. In addition, the stone pine is known to be a masting species with different cone and flower formation mainly affected by weather conditions [2,11].

Located on the eastern edge of the Mediterranean Sea, Lebanon is a country where stone pine forests are economically important, contributing directly to the livelihood of at least 1000 rural families [12]. Stone pine forests extend over approximatively 12,740 ha and represent $9.3 \%$ of the total forest cover of the country [13-15]. Umbrella pine is a typical masting habit species, showing huge interannual cone production variability mainly ruled by climatic factors, especially rainfall events occurring at key moments in the cone development cycle [11]. Pine nut production is variable and ranges from $<200$ to $>5000 \mathrm{~kg} / \mathrm{ha}$ [16]. During the last decade, the main producing countries in the Mediterranean basin have reported a dramatic decline in cone production per hectare and a high percentage of empty kernels per cone [2,17]. From 2012, similar symptoms have been detected in Lebanon; dry cone syndrome (DCS), associated with empty pine seeds and dried conelets, has been found in many stone pine stands across the country [12]. These symptoms are reported to be caused either by the invasive conifer seed bug Leptoglossus occidentalis [18-23], or by other biotic and abiotic factors as a result of climate change and droughts, as reported by others [2,4,24-26]. Additionally, Pinus pinea is threatened by the fungus Diplodia pinea, and an association between L. occidentalis and this fungus was detected in Mediterranean forests [27].

Leptoglossus occidentalis Heidemann (Heteroptera Coreidae) is a polyphagous cone and seed predator, commonly known as the western conifer seed bug. It is native to the western part of North America, from British Columbia in the north to Veracruz in Mexico in the south; Montana, Wyoming and Colorado correspond to the eastern boundaries [28,29]. In North America, its feeding has been described as a likely cause of conelet abortion. It has also caused a significant reduction in seed production that is critical for pine reforestation [30-35]. Moreover, it has affected pine nut production in Mediterranean Europe by damaging pine seeds directly or indirectly when vectoring the fungus Diplodia sapinea [7]. The pest was first recorded in Europe in 1999 in Italy [36], where years later, serious losses in P. pinea nut production of up to $90 \%$ were reported [18,37]. In the Iberian Peninsula, the pest was reported in 2004 in Catalonia by Ribes and Oscala [38], afterwards throughout the Spanish Regions [19,39-41] and reached Portugal in 2010 [42,43]. The species has invaded almost the entire continent of Europe only in 10 to 15 years [44-46]; this fast invasion in Europe was enhanced by multiple introductions and human-eased transportation [47]. The insect then continued its expansion towards other Mediterranean and Asian countries, and was recorded in eastern Turkey [48], east Asia [49-51], and in North Africa in Tunisia [52] and Morocco [53]. In 2015, it was detected in Lebanon [12] and, more recently, in Crete and in the northern part of the Golan Heights [54,55]. The invasion continues and new records from different countries in Africa, South America and Europe have been recorded from 2019 until 2021 [56-63].

The main objective of this study is to quantify the recent decline in cone production and kernel nuts by investigating the relationship between cone production and prevailing climatic factors in Lebanon between 2009 and 2017. The study also aimed to compare pine cone production and the percentage of empty seeds in two periods, before and after 2012, considering a probable establishment of L. occidentalis in the country around that year.

\section{Materials and Methods}

\subsection{Investigated Areas and Data Collection}

Pinus pinea forests in Lebanon cover mainly two regions, which are similar in terms of their environmental conditions, management traditions and practices. Data were collected yearly from 2008 to 2017 in 24 forest sites located in two different districts in Mount Lebanon: 16 sites in Baabda district and 8 sites in Jezzine district (Figure 1). Cone production was calculated per hectare. Data concerning cone production and empty seeds in the last 9 years 
were provided by the "Lebanese Pine Farmers Association". The values are presented in the form of average \pm SD.

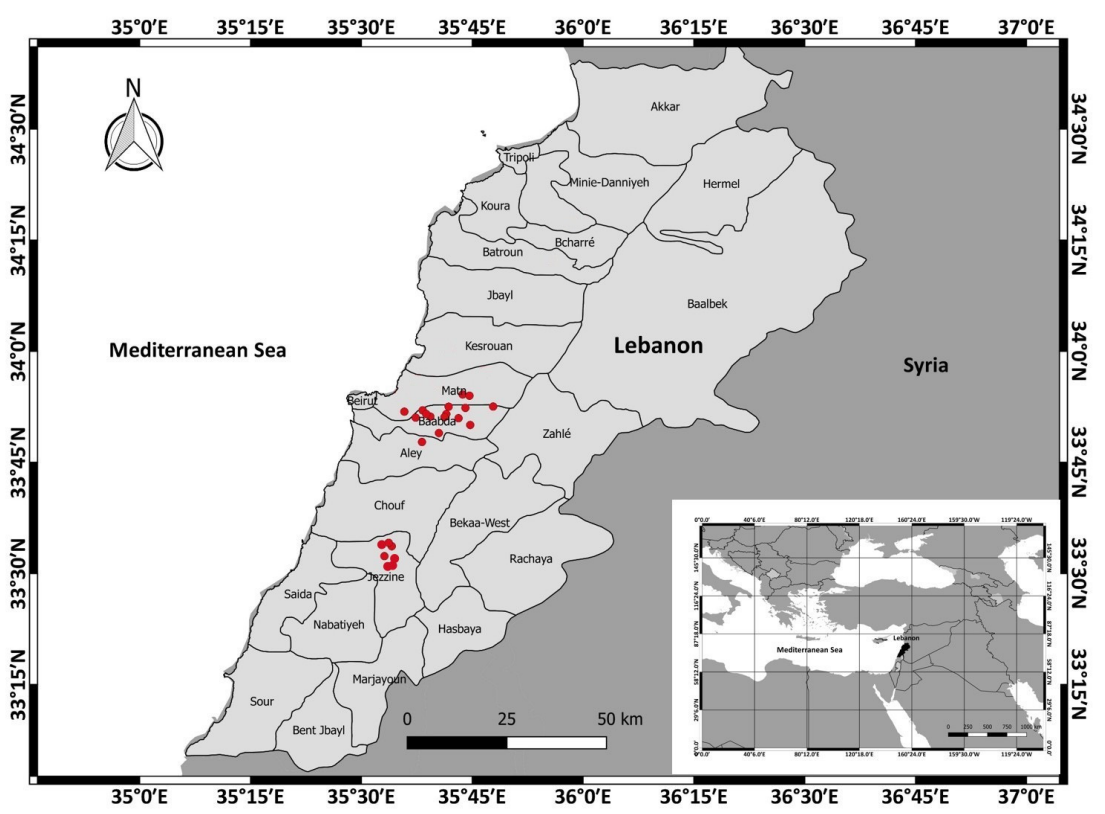

Figure 1. Map of the studied forest sites in Lebanon.

\subsection{Post Harvesting Phase and Data Analysis}

Cone harvest is performed yearly by specialized tree climbers between mid-November and the end of February. After harvest, the cones are gathered and stored either indoors until mid-May in aerated bags or on the ground over thick nylon layers in the forests; this provides both moisture and good aeration. Around mid-May, the cones are laid out and exposed to sunlight for 10 to 15 days until ripening. The cones are then ground in mills, and pine nuts are subsequently separated from scales and fragments using sieves and cyclones. Shelled pine nuts are then immersed in large water basins for two purposes: water-soaked shells are more elastic, and thus, less prone to kernel breakage, and empty nuts floating on the surface can be easily discarded. Empty nuts are considered a waste product and may serve as fuel for residential heating.

The cone production unit was standardized to $\mathrm{Mg} / \mathrm{ha} /$ year and the percentage of empty seeds in the final kernel yield was calculated by volume. Climatic data were obtained from the Department of Meteorology-General Direction of Civil Aviation in Lebanon. Annual rainfall ranged from 850 to $1350 \mathrm{~mm}$ per year in Baabda and Jezzine, and the annual mean temperatures ranged between 17 and $20^{\circ} \mathrm{C}$. Each site received an average of $200 \mathrm{~mm}$ of rainfall during spring and summer seasons, with the exception of the year 2010, where rainfall during both seasons was $50 \mathrm{~mm}$ (Figure 2).

Statistical analyses and plots were performed using R 3.5.1 [64] software in RStudio 1.1.463 [65]. Line plots were generated using the package g.gplot2 [66].

Prior to performing the correlation analysis, the assumptions for parametric statistics were checked. Normality of data distribution was tested using the package fitdistrplus [67] in combination with a Shapiro-Wilk test and Kolmogorov-Smirnov test, and homoscedasticity was tested using Bartlett's test and Levene's test. Repeated measures two-way ANOVA on transformed data (log(Production) and arcsin(sqrt(Empty Seeds)) was performed, to study the differences in cone production and empty seeds between the districts and according to the time where a drop in cone yield and an increase in empty seeds was observed, i.e., 2012-2013. Observations on the same pine stands each year were considered as repeated measures. District (two levels: Baabda and Jezzine) and time period (two levels: 2008-2012 and 2013-2017) were used as fixed factors in ANOVA. 


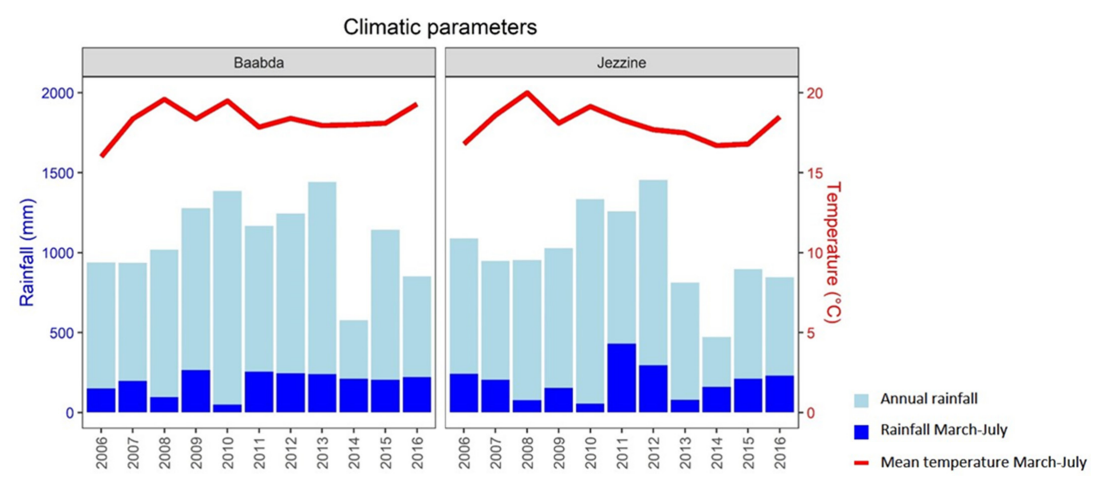

Figure 2. Averages of mean annual rainfall (mm), growing season and cone initiation (March-July), rainfall (mm) and temperature $\left({ }^{\circ} \mathrm{C}\right)$ from 2006 to 2016. Reference: Department of MeteorologyGeneral Direction of Civil Aviation in Lebanon.

The Pearson correlation between annual cone production and percentage of damaged/empty seeds was tested. Correlations were studied between climatic conditions and cone yield production and empty seed percentages. The climatic variables considered were as follows: the total annual rainfall, the average temperature of the three hottest months (June, July, and August), and the average temperature of the three coldest months (January, February, and March). The latter variables were measured in the year of maturation ( $t)$, one year before ( $\mathrm{t}-1)$ and two years before $(\mathrm{t}-2)$. In addition, total seasonal rainfall and average temperatures measured during cone initiation ( $t-2)$ were reported from March to July.

\section{Results}

\subsection{Pine Production 2008-2017}

Between 2008 and 2012, cone production in the selected forests gave an average yield of $3.1 \pm 3.1(\mathrm{Mg} / \mathrm{ha})$ and a relatively low percentage of damaged/empty seeds $(6.5 \pm 3.3)$ (Figure 3). However, cone production dropped to $1.5 \pm 1.7 \mathrm{Mg} /$ ha between 2012 and 2017, and the percent of damaged empty seeds averaged $41.8 \% \pm 20.8 \%$ of the total annual yield (Figure 3). Our results show that time periods significantly affected both cone production $(\mathrm{df}=1 ; \mathrm{F}=86.1 ; p<0.0001)$ and empty seeds $(\mathrm{df}=1 ; \mathrm{F}=296.995 ; p<0.0001)$. There was a significant negative correlation between production of pine cones and damaged/empty seed percentages $(\mathrm{r}=-0.42 ; p<0.001)$. The percentage of damaged/empty seeds increased and cone production decreased in 2012/2013 in Baabda and in 2013/2014 in Jezzine (Figure 3). There was no significant difference between districts, neither for production $(\mathrm{df}=1 ; \mathrm{F}=0.001 ; p=0.654)$ nor for empty seeds $(\mathrm{df}=1 ; \mathrm{F}=2.597 ; p=0.1227)$.
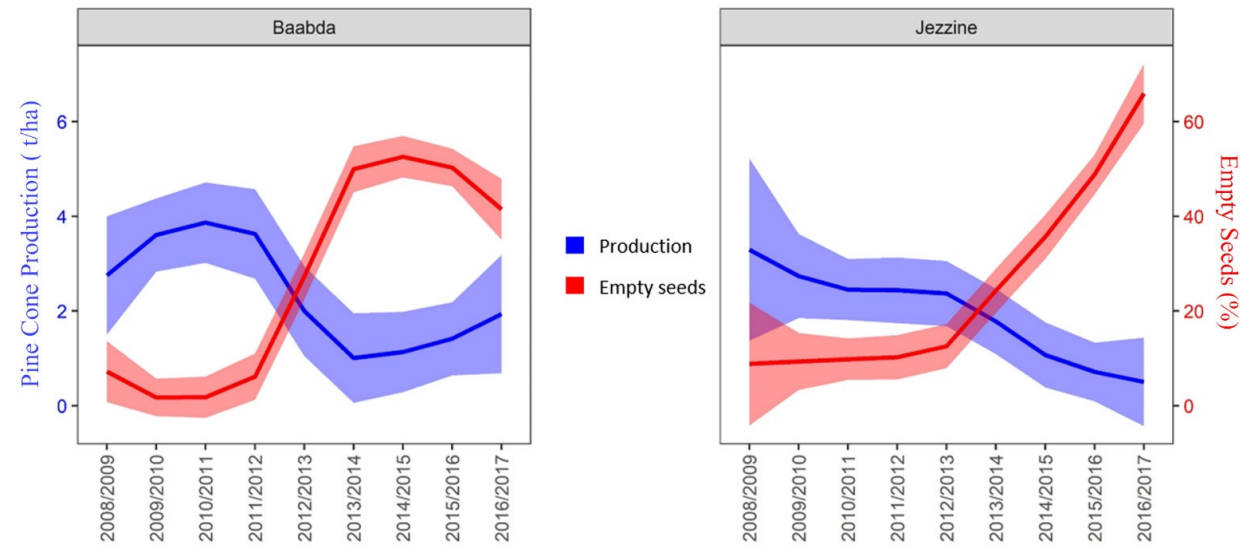

Figure 3. Pine cone production (in blue) and percentage of damaged/empty seeds (in red) over the years in two districts of Lebanon: Baabda $(\mathrm{N}=16)$ and Jezzine $(\mathrm{N}=8)$. Lines represents the mean of replicates (Forest sites), and shades are the $95 \%$ confidence interval of the mean. 


\subsection{Climatic Variables Effect}

A significant positive correlation was found between cone production and average temperatures during the year of cone initiation (March-July) $(r=0.54, p=0.032)$. Empty seed percentages were correlated with temperature in the hottest three months of the year of harvesting ( $\mathrm{t})(p=0.019)$. Empty seeds and temperature in the hottest months $(\mathrm{t}-2)$ were negatively but not significantly correlated $(r=-0.45, p=0.079)$. Rainfall in the year of harvesting $(\mathrm{t})$ was positively but not significantly correlated with cone production $(\mathrm{r}=0.47$; $p=0.068$ ) (Figure 4). Similarly, rainfall was negatively but not significantly correlated with the percentage of empty seeds $(r=-0.47 ; p=0.068)$ (Figure 5).
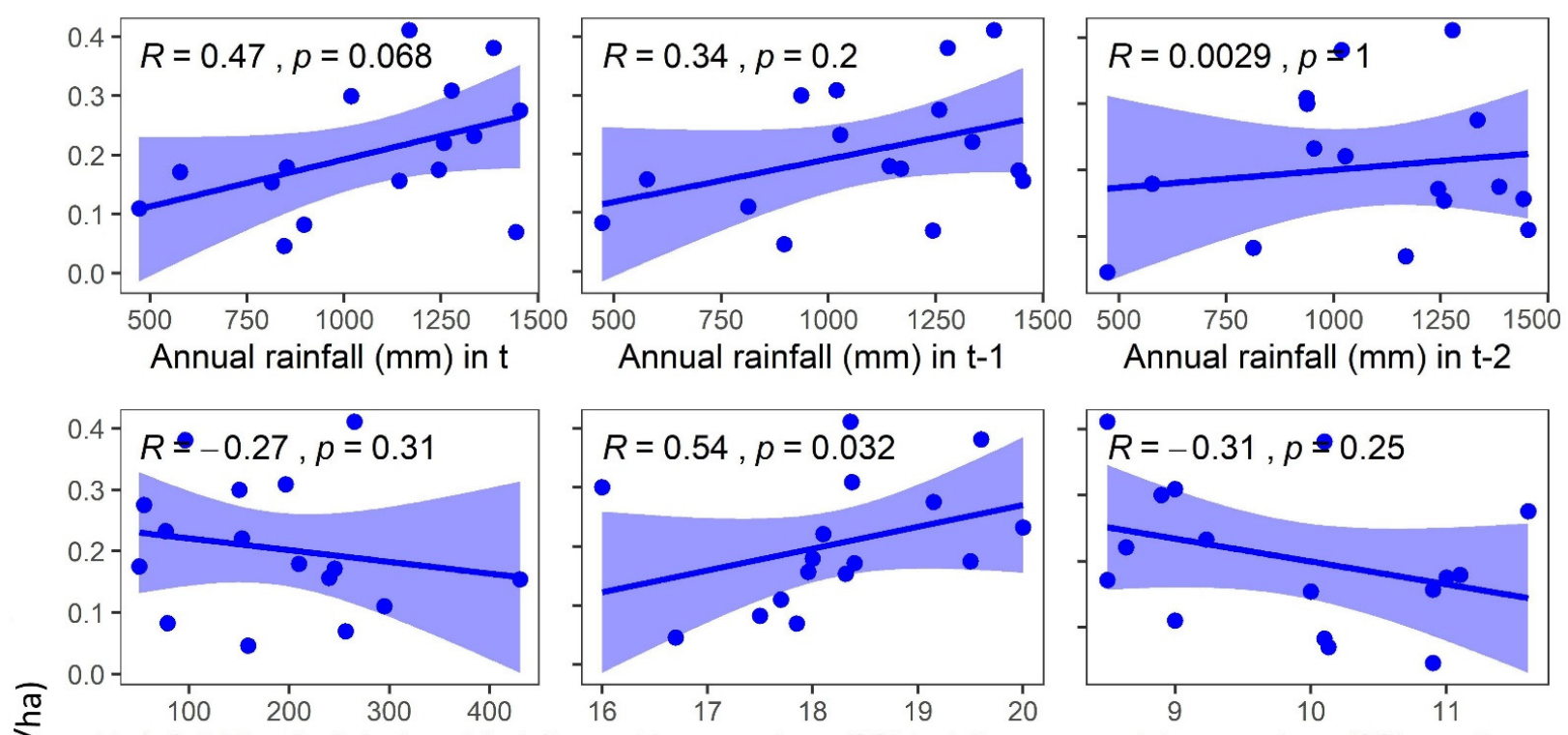

Rainfall March-July (mm) in t-2

Temperature $\left({ }^{\circ} \mathrm{C}\right)$ in $\mathrm{t}-2$
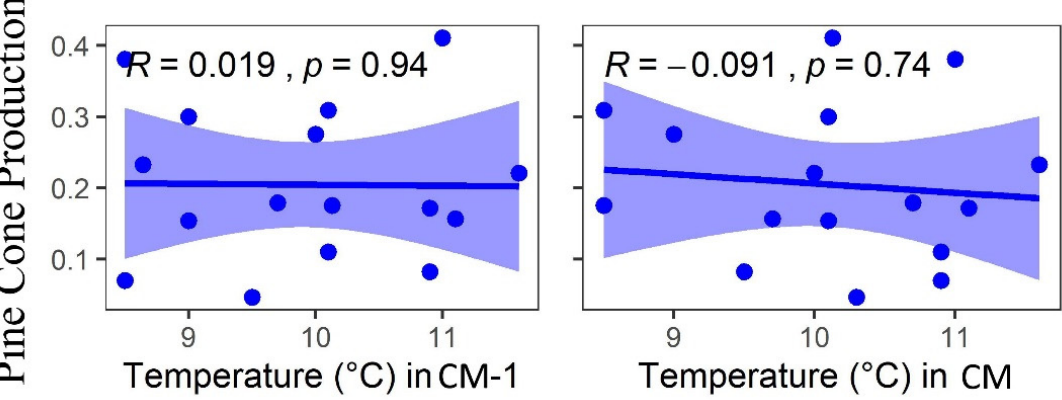

Temperature $\left({ }^{\circ} \mathrm{C}\right) \mathrm{CM}-2$
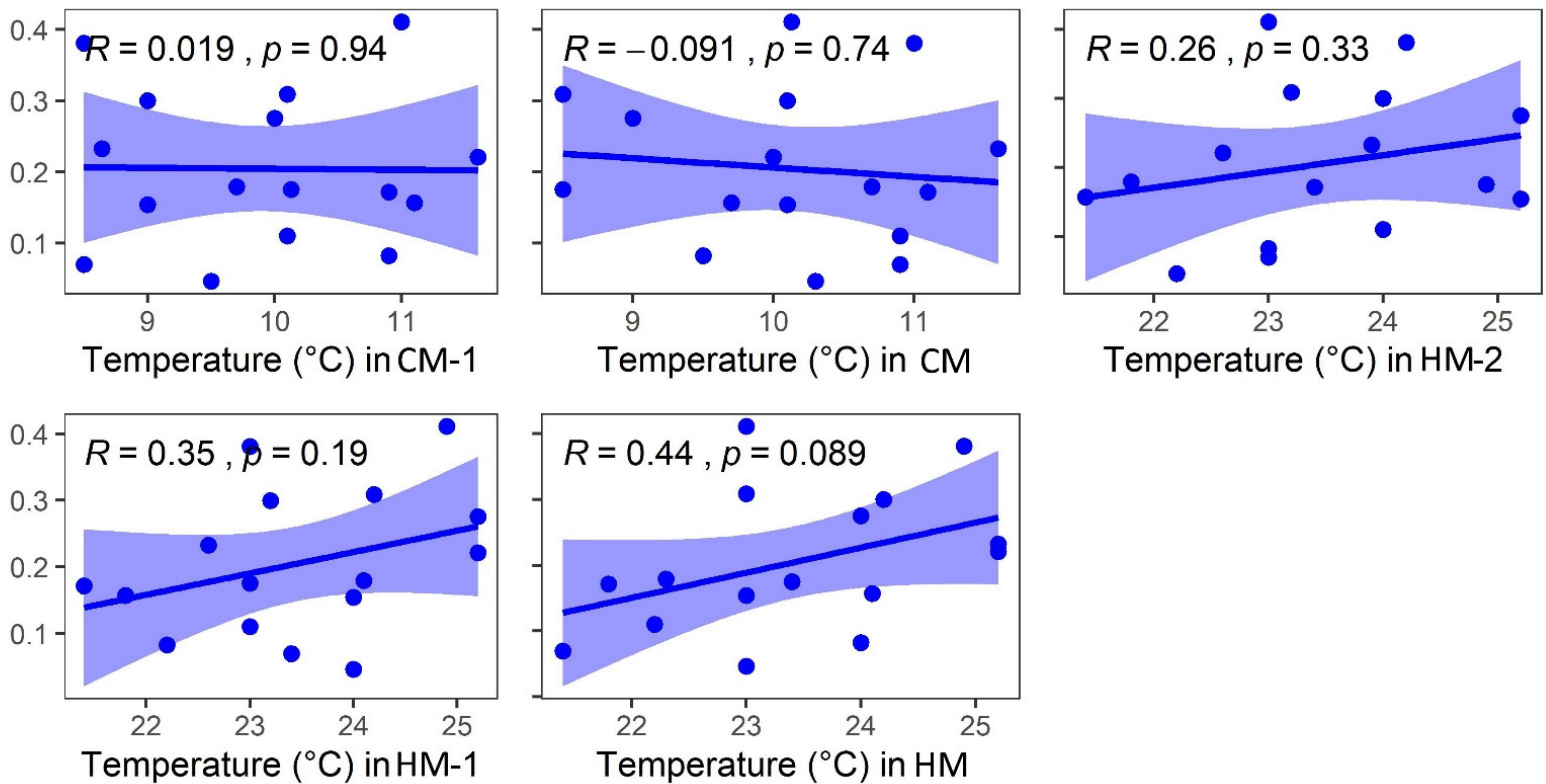

Figure 4. Summary of Pearson correlation between pine cone production and climatic variables in Lebanon. $t$-year of harvesting; $\mathrm{t}-1$ - one year before the year of harvesting; $\mathrm{t}-2$ - $\mathrm{two}$ years before the year of harvesting; $\mathrm{CM}-$ coldest months in the year of harvesting; CM-1—coldest months one year before the year of harvesting; CM-2—coldest months two years before the year of harvesting; HM-hottest months in the year of harvesting; HM-1—hottest months one year before the year of harvesting; HM-2-hottest months two years before the year of harvesting. 

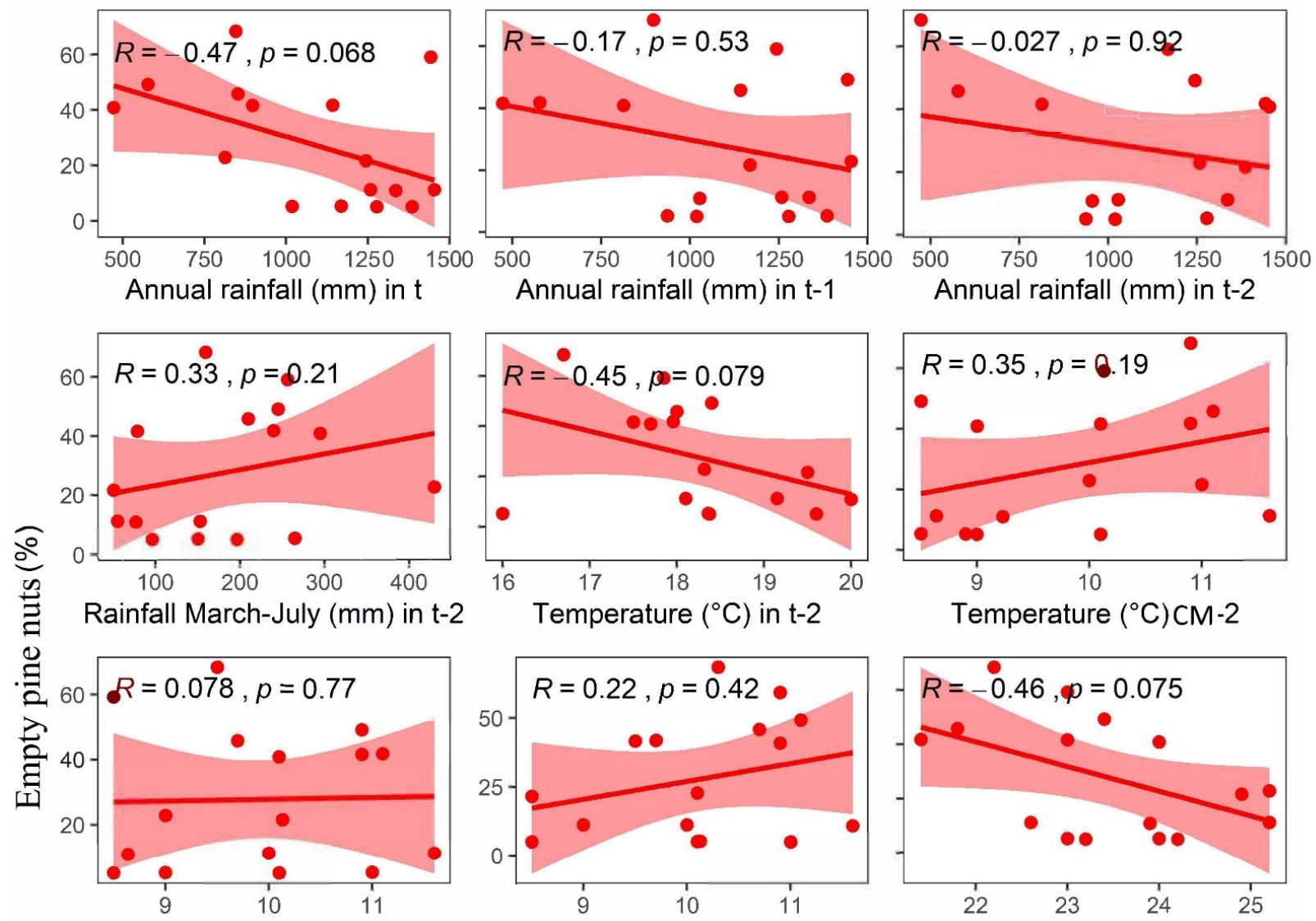

Temperature $\left({ }^{\circ} \mathrm{C}\right) \mathrm{CM}-2$
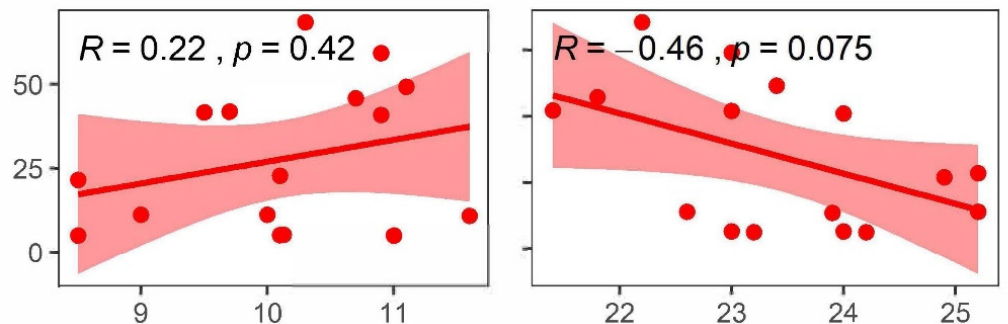

Temperature $\left({ }^{\circ} \mathrm{C}\right)$ in $\mathrm{CM}-1$

Temperature $\left({ }^{\circ} \mathrm{C}\right)$ in $\mathrm{CM}$
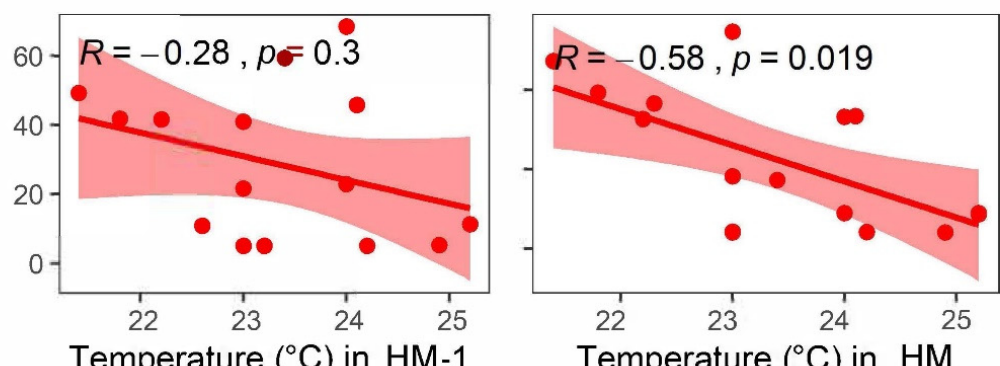

Temperature $\left({ }^{\circ} \mathrm{C}\right)$ in $\mathrm{HM}-2$

Temperature $\left({ }^{\circ} \mathrm{C}\right)$ in $\mathrm{HM}-1$

Temperature $\left({ }^{\circ} \mathrm{C}\right)$ in $\mathrm{HM}$

Figure 5. Summary of Pearson correlation between the percentage of empty seeds and climatic variables in Lebanon. $\mathrm{t}$-year of harvesting; $\mathrm{t}-1$ - one year before the year of harvesting; $\mathrm{t}-2$ - two years before the year of harvesting; $\mathrm{CM}-\mathrm{coldest}$ months in the year of harvesting; CM-1 — coldest months one year before the year of harvesting; CM-2-coldest months two years before the year of harvesting; HM-hottest months in the year of harvesting; HM-1-hottest months one year before the year of harvesting; HM-2-hottest months two years before the year of harvesting.

Cone production and empty/damaged seeds were not significantly correlated with most climatic variables investigated during the three-year cycle of cone development (Figures 4 and 5).

\section{Discussion}

Following the decline in pine nut production in Lebanon, abiotic factors were investigated to determine the principal reasons for this decline. This study, therefore, analyzed the relationship between the decline in pine nut production, the increase in damaged/empty seeds, and climatic factors during the last decade.

The reported data show that this decade can be divided into two distinct phases:

(1) normal cone production with negligible empty seed percentages before 2012, and (2) a sharp decline in cone production $(\mathrm{Mg} / \mathrm{ha} /$ year) associated with a sudden increase in 
damaged/empty seeds after 2012. This striking collapse in pine nut yield can be attributed to several factors, including unsuccessful pollination or fertilization, and ovule abortion due to climatic factors.

Our data showed that cone yield production per hectare and percentage of damaged/empty seeds were significantly negatively correlated. There is a simple direct relationship between cone production $(\mathrm{Mg} / \mathrm{ha})$ and the percentage of empty seeds, as the latter affects the weight of the cone. Thus, an increase in the number of empty seeds would mean a decrease in cone weight. However, nut yield represents $3.5-5 \%$ of the total cone weight [68-70], and the observed decrease in Lebanon's pine cone production between the different periods of years (before and after 2012-2013) amounts to 50\% (Figure 3), suggesting that this decrease is mainly due to the abortion of conelets rather than to empty seeds. Although the presented data confirm that the decline in nut production started in 2012, there is growing evidence that the causal agent of this decline could be attributed to a biotic causal agent and particularly L. occidentalis [71], an insect already detected in Lebanon. As this insect was reported in Turkey in 2009 [44], Nemer [12] (2015) suggested that it could have been introduced and established in Lebanon several years before its first detection. According to the scientific literature, damage caused by L. occidentalis on conifers include conelet abortion, total seed per cone reduction, and empty or partially filled seeds $[22,25,29,30,35,45,72-74]$.

Further studies on pine species demonstrated that climatic conditions during seed cone initiation may strongly influence seed and cone production $[2,75,76]$. Although most correlations did not show a tangible significant effect of temperatures and rainfall on production, the influence of climate should not be neglected, since the introduction of infectious diseases and alien pests into new countries has often been associated with climate change, human ecology, and increased global trade [77]. Although not significant in our study, rainfall in the year of harvesting $(t)$ may have had a positive effect on cone production (Figure 4) and the decrease in the number of empty seeds (Figure 5), suggesting that rainfall is probably among the factors that regulate cone production, in agreement with the work of Calama et al. [69] and Loewe-Munoz et al. (2016). In addition, a reduction in rainfall in Jezzine after 2013 may have affected the increase in empty seeds (Figure 3). In agreement with Loewe-Munoz et al. [78], average temperature during the period of cone initiation t-2 positively affects cone production (Figure 4). However, Redmond et al. [76] stated that increases in temperature lead to a decrease in cone and seed production. Moreover, the influence of climate on the phenology of stone pine in Lebanon should not be automatically excluded. For example, there is evidence that a temperature increase in the last month of winter affected the phenology of trees in Germany [79]. Furthermore, Loewe-Muñoz et al. [78] showed a significant effect of climate on pine growth in Chile, although these effects were not reflected in cone productivity. Therefore, although the climate variables' effect may not be tangible, their effect should be taken into consideration, since they may influence other physiological processes.

Several studies have attempted to determine the cause of such a decline in pine nut production. Most of them attributed the cause to an infestation of L. occidentalis, which may affect the cones and conelets as well $[25,31,33]$.

A one-year delay in the decline in pine nut production was observed between the two forest sites, suggesting that the infestation may have extended to the south of Lebanon. The sudden increase in empty seeds in Jezzine in south Lebanon was observed in 2013, whereas the same rapid increase was observed in Baabda forests in 2012. This could indicate that a progressive infestation may have played a decisive role in the decline in cone production. Moreover, the decrease in rainfall observed in 2013 in Jezzine could have had an impact on production (Figure 2).

Since Lebanese pine stands are characterized by tall tree canopies, harvesting may be complex and often requires skilled tree climbers. This means that labor is often expensive, and this is a further reason for the high price of the final product. The recent scarcity of 
pine nut kernels has, therefore, generated additional labor costs to maintain the same levels of profitability. This problem places the pine nut value chain in a challenging situation.

The decline in pine seed production in Lebanon is a major concern involving a wide variety of socioeconomic and environmental aspects. Not only could the fragile rural economic sector be affected, but the decline may negatively affect the vegetative regeneration ability of Pinus pinea.

In light of our results, losses in pine nut yield may not be correlated to climatic factors alone; the presence of L. occidentalis may also play a role in threatening pine nut production in Lebanon. For this reason, there is a need for further investigations, and it is particularly important to examine the phenology of P. pinea in Lebanon.

Author Contributions: Conceptualization, N.N.; Data curation, Y.E.K.; Formal analysis, G.B.; Funding acquisition, E.N. and N.N.; Methodology, Y.E.K.; Project administration, E.N. and N.N.; Resources C.A.K. and N.N.; Software, G.B.; Supervision, E.T.; Validation, N.N. and E.T.; Writing-original draft, Y.E.K.; Writing-review and editing, Y.E.K., E.N. and N.N. All authors have read and agreed to the published version of the manuscript.

Funding: This research was funded by the National Council for Scientific Research in Lebanon (CNRS-L) and the Holy Spirit University of Kaslik USEK Lebanon.

Institutional Review Board Statement: Not applicable.

Data Availability Statement: Not applicable.

Acknowledgments: The authors would like to acknowledge the National Council for Scientific Research in Lebanon (CNRS-L) for granting a doctoral fellowship to Yara El Khoury and a grant research fund for this project. Noujeim also acknowledges the "L'OREAL-UNESCO foundation" for granting her a regional fellowship "L'OREAL-UNESCO for women in science, Levant and Egypt" on this project. We would like to thank Sarah Jane Christopher for her language editing and review of this MS. Special thanks to Chadi Abdallah for providing pine maps, Elias Nouaimeh for the provided data on pine nuts production, and Nemer Zein for his support during the field work.

Conflicts of Interest: The authors declare no conflict of interest.

\section{References}

1. Barbero, M.; Loisel, R.; Quezel, P.; Richardson, D.M.; Romane, F. Pines of the mediterranean basin. In Ecology and Biogeography of Pinus; Richardson, D.M., Rundel, P.W., Eds.; Cambridge University Press: Cambridge, UK, 1998; pp. 153-170.

2. Mutke, S.; Gordo, J.; Gil, L. Variability of Mediterranean Stone pine cone production: Yield loss as response to climate change. Agric. For. Meteorol. 2005, 132, 263-272. [CrossRef]

3. Mutke, S.; Calama, R.; González-Martínez, S.C.; Montero, G.; Gordo, F.J.; Bono, D.; Gil, L. Mediterranean stone pine: Botany and horticulture. Hortic. Rev. 2012, 39, 153-201.

4. Calama, R.; Gordo, J.; Madrigal, G.; Mutke, S.; Conde, M.; Montero, G.; Pardos, M. Enhanced tools for predicting annual stone pine (Pinus pinea L.) cone production at tree and forest scale in Inner Spain. For. Syst. 2016, 25, 3. [CrossRef]

5. Hamade, K.; FAO. Non-Wood Forest Product Value Chains in Lebanon. 2016. Available online: www.fao.org/publications (accessed on 10 December 2020).

6. Ovando, P.; Campos, P.; Calama, R.; Montero, G. Landowner net benefit from stone pine (Pinus pinea L.) afforestation of dry-land cereal fields in Valladolid, Spain. J. For. Econ. 2010, 16, 83-100. [CrossRef]

7. Awan, H.U.M.; Pettenella, D. Pine nuts: A review of recent sanitary conditions and market development. Forests 2017, 8, 367. [CrossRef]

8. Scarascia-Mugnozza, G.; Oswald, H.; Piussi, P.; Radoglou, K. Forests of the Mediterranean region: Gaps in knowledge and research needs. For. Ecol. Manag. 2000, 132, 97-109. [CrossRef]

9. Loewe-Muñoz, V.; Delard, C. Effect of irrigation in growth and fruit production in stone pine (Pinus pinea L.) in Chile. In Proceedings of the XXIX International Horticultural Congress on Horticulture: Sustaining Lives, Livelihoods and Landscapes (IHC2014), Brisbane, Australia, 17 August 2014; Volume 1130, pp. 537-544.

10. Valdiviesso, T.; Pimpao, M.; Trindade, C.S.; Varela, M.C. Reproductive phenology of Pinus pinea. Méditerranéennes Série A Séminaires Méditerranéens 2017, 122, 63-68.

11. Pereira, S.; Prieto, A.; Calama, R.; Diaz-Balteiro, L. Optimal management in Pinus pinea L. stands combining silvicultural schedules for timber and cone production. Silva Fenn. 2015, 49, 1226. [CrossRef] 
12. Nemer, N.; FAO. Report on Insect Pests Associated with Conelet Losses and Their Management in Pinus Pinea Forests in Lebanon. Lebanon. 2015. Available online: www.researchgate.net/publication/313471959_Report_on_insect_pests_associated_with_ conelet_losses_and_their_management_in_Pinus_pinea_forests_in_Lebanon (accessed on 6 January 2021).

13. FAO. National Forest and Tree Assessment and Inventory TCP/LEB/2903 Final Report. 2005. Available online: www.fao.org/ forestry/15565-0f921641e230ef06f11d15b8856f2ff07.pdf (accessed on 6 January 2021).

14. FAO. Country Report Lebanon. Global Forest Resources Assessment 2010. 2010. Available online: www.fao.org/3/i1757e/i1757e. pdf (accessed on 8 January 2021).

15. Nakhoul, J.; Fernandez, C.; Bousquet-Mélou, A.; Nemer, N.; Abboud, J.; Prévosto, B. Vegetation dynamics and regeneration of Pinus pinea forests in Mount Lebanon: Towards the progressive disappearance of pine. Ecol. Eng. 2020, 152, 105866. [CrossRef]

16. Gorrieri, L.; Cecchini, C. Antichi Mestieri Rurali Nel Territorio Del Parco; Felici Editore: Italy, 2010; 157p.

17. Roversi, P.F.; Strong, W.B.; Caleca, V.; Maltese, M.; Peverieri, G.S.; Marianelli, L.; Marziali, L.; Strangi, A. Introduction into Italy of Gryon pennsylvanicum (Ashmead), an egg parasitoid of the alien invasive bug Leptoglossus occidentalis Heidemann. EPPO Bull. 2011, 41, 72-75. [CrossRef]

18. Roversi, P.F. Adattamento di specie neo-introdotte, Leptoglossus occidentalis Heidemann. In Insetti Esotici e Tutela Ambientale; Arti Grafiche Maspero Fontana and C: Cermenate, Italy, 2009; pp. 224-229.

19. Vázquez, M.Á.; Costas, M.; Outerelo, R.; Melero-Alcíbar, R. Una chinche invasora en la Comunidad de Madrid: Leptoglossus occidentalis Heidemann, 1910 (Hemiptera: Heteroptera: Coreidae). Heteropterus Rev. Entomol. 2009, 9, 49-51.

20. Bracalani, M.; Benedettelli, S.; Croci, F.; Terreni, P.; Tiberi, R.; Panzavolta, T. Cone and seed pests of Pinus pinea: Assessment and characterization of damage. J. Econ. Entomol. 2013, 106, 229-234. [CrossRef]

21. Parlak, S. An invasive species: Leptoglossus occidentalis (Heidemann) how does it affect forestry activities? Kast. Univ. J. For. Fac. 2017, 17, 531-542. [CrossRef]

22. Farinha, A.O.; Branco, M.; Pereira, M.F.; Auger-Rozenberg, M.-A.; Maurício, A.; Yart, A.; Guerreiro, V.; Sousa, E.M.R.; Roques, A. Micro X-ray computed tomography suggests cooperative feeding among adult invasive bugs Leptoglossus occidentalis on mature seeds of stone pine Pinus pinea: Consumption of P. pinea seeds by L. occidentalis. Agric. For. Entomol. 2018, $20,18-27$. [CrossRef]

23. Nemer, N.; El Khoury, Y.; Noujeim, E.; Zgheib, Y.; Tarasco, E.; Van Der Heyden, T. First records of the invasive species Leptoglossus occidentalis Heidemann (Hemiptera: Coreidae) on different coniferous species including the cedars of Lebanon. Rev. Chil. Entomol. 2019, 45, 507-513. [CrossRef]

24. Calama, R.; Mutke, S.; Tomé, J.; Gordo, J.; Montero, G.; Tomé, M. Modelling spatial and temporal variability in a zero-inflated variable: The case of Stone pine (Pinus pinea L.) cone production. Ecol. Model. 2011, 222, 606-618. [CrossRef]

25. Farinha, A.C.O.; Silva, J.E.P.; Correia, A.C.; Sousa, E.M.R.; Roques, A.; Branco, M. Is Leptoglossus occidentalis entirely responsible for the high damage observed on cones and seeds of Pinus pinea? Results from a fertirrigation trial in Portugal. For. Ecol. Manag. 2018, 429, 198-206. [CrossRef]

26. El Khoury, Y.; Binazzi, F.; Nemer, N.; Noujeim, E.; Tarasco, E.; Roversi, P.F.; Pennachio, F. Bark beetles (Coleoptera Curculionidae Scolytinae) associated with Pinus pinea in Lebanon: New records with remarks on their ecology, distribution and potential threat for forest stands. Redia 2019, 102, 121-128. [CrossRef]

27. Luchi, N.; Mancini, V.; Feducci, M.; Santini, A.; Capretti, P. Leptoglossus occidentalis and Diplodia pinea: A new insect-fungus association in Mediterranean forests. For. Pathol. 2012, 42, 246-251. [CrossRef]

28. Heidemann, O. New species of Leptoglossus from North America. Proc. Entomol. Soc. 1910, 12, 191-197.

29. Koerber, T.W. Leptoglossus occidentalis (Hemiptera, Coreidae), a Newly Discovered Pest of Coniferous Seed. Ann. Entomol. Soc. Am. 1963, 56, 229-234. [CrossRef]

30. Bates, S.L.; Strong, W.B.; Borden, J.H. Abortion and seed set in lodgepole and western white pine conelets following feeding by Leptoglossus occidentalis (Heteroptera: Coreidae). Environ. Entomol. 2002, 31, 1023-1029. [CrossRef]

31. Strong, W.B.; Bates, S.L.; Stoehr, M.U. Feeding by Leptoglossus occidentalis (Hemiptera: Coreidae) reduces seed set in lodgepole pine (Pinaceae). Can. Entomol. 2001, 133, 857-865. [CrossRef]

32. Strong, W.B. Seasonal changes in seed reduction in lodgepole pine cones caused by feeding of Leptoglossus occidentalis (Hemiptera: Coreidae). Can. Entomol. 2006, 138, 888-896. [CrossRef]

33. Mutke, S.; Martinez, J.; Gordo, J.; Nicolas, J.L.; Herrero, N.; Pastor, A.; Calama, R. Severe seed yield loss in Mediterranean stone pine cones (Pinus pinea). In Proceedings of the 5th International Conference on Mediterranean Pines (MedPine5), Solsona, Spain, 26 September 2014; pp. 22-26.

34. Calama, R.; Manso, R.; Barbeito, I.; Madrigal, G.; Garriga, E.; Gordo, F.J.; Montero, G.; Cañellas, I.; Pardos, M. Do inter-specific differences in seed size determine natural regeneration traits in Pinus pinea and Pinus sylvestris? Appl. Ecol. Environ. Res. 2015, 13, 387-404. [CrossRef]

35. Strong, W. Lodgepole pine seedset increase by mesh bagging is due to exclusion of Leptoglossus occidentalis (Hemiptera: Coreidae). J. Entomol. Soc. Br. Columbia 2015, 12, 3-18.

36. Tescari, G. Leptoglossus occidentalis, coreide neartico rinvenuto in Italia (Heteroptera, Coreidae). Lav. Soc. Veneziana Sci. Nat. 2001, 26, 3-5.

37. Santini, L. La cimice americana delle conifere Leptoglossus occidentalis Heidemann (Heteroptera, Coreidae) e fruttificazione del pino domestic. Georgofili 2009, 6, 15-35. 
38. Ribes, J.; Escolà, O. Leptoglossus occidentalis Heidemann, 1910, a Nearctic bug (Hemiptera, Heteroptera, Coreidae) found in Catalonia, Spain. Sess. Conjucta d'Entomologia 2005, 43, 47-50, ICHN-SCL 13,47-50.

39. Pagola-Carte, S. Leptoglossus occidentalis Heidemann (Heteroptera, Coreidae), chinche invasora en la cornisa cantábrica ibérica. Heteropterus Rev. Entomol. 2009, 9, 175-178.

40. Valvárcel, J.P.; Portillo, P. NOTA BREVE Primer registro de Leptoglossus occidentalis Heidemann, 1910 (Hemiptera, Coreidae) para Murcia (S.E. de la Península Ibérica). Arq. Entomolóxicos 2009, 2, 5.

41. Valvárcel, J.P.; Prieto Pilona, F. Primeros registros de Leptoglossus occidentalis Heidemann, 1910 (Hem., Coreidae) para Galicia (N.O. Península Ibérica). Arq. Entomolóxicos 2010, 4, 26.

42. Grosso-Silva, J.M. The north american western conifer seed bug, Leptoglossus occidentalis Geidemann, 1910 (Hemiptera, Coreidae), new to Portugal. Arq. Entomoloxicos 2010, 4, 37-38.

43. Sousa, E.; Naves, P. The western conifer seed bug Leptoglossus occidentalis Heidemann, 1910 (Heteroptera: Coreidae) in Portugal. Boletín Sanid. Veg. Plagas 2011, 37, 65-67.

44. Fent, M.; Kment, P. First record of the invasive western conifer seed bug Leptoglossus occidentalis (Heteroptera: Coreidae) in Turkey. North-West. J. Zool. 2011, 7, 72-80.

45. Lesieur, V.; Yart, A.; Guilbon, S.; Lorme, P.; Auger-rozenberg, M.A.; Roques, A. The invasive Leptoglossus seed bug, a threat for commercial seed crops, but for conifer diversity? Biol. Invasions 2014, 16, 1833-1849. [CrossRef]

46. Mutke, S.; Calama, R.; Montero, G.; Gordo, J. Pine nut production from forests and agroforestry systems around the Mediterraneana short overview. In Proceedings of the COST Action FP1203 Workshop and MC Meeting, Zagreb, Croatia, 18-20 February 2015.

47. Lesieur, V.; Lombaert, E.; Guillemaud, T.; Courtial, B.; Strong, W.; Roques, A.; Auger-Rozenberg, M.A. The rapid spread of Leptoglossus occidentalis in Europe: A bridgehead invasion. J. Pest Sci. 2019, 92, 189-200. [CrossRef]

48. Özgen, İ.; Dioli, P.; Çelik, V. New and Interesting record of western conifer seed bug: Leptoglossus occidentalis (Heidemann, 1910) (Heteroptera: Core1dae) in Eastern Turkey. J. Entomol. Zool. Stud. 2017, 5, 830-833.

49. Ishikawa, T.; Kikuhara, Y. Leptoglossus occidentalis Heidemann (Hemiptera: Coreidae), a presumable recent invader to Japan. Jpn. J. Appl. Entomol. 2009, 12, 115-116.

50. Zhu, W.B. Exotic coreid bugs introduced into China. In Proceedings of the 4th Meeting of the International Heteropterist's Society, Nankai University, Tianjin, China, 12-17 July 2010; p. 71.

51. Ahn, S.J.; Son, D.; Choo, H.Y.; Park, C.G. The first record on Leptoglossus occidentalis (Hemiptera: Coreidae) in Korea, a potential pest of the pinaceous tree species. J. Asia-Pac. Entomol. 2013, 16, 281-284. [CrossRef]

52. Jamaa, M.L.B.; Mejri, M.; Naves, P.; Sousa, E. Detection of Leptoglossus occidentalis Heidemann 1910 (Heteroptera: Coreidae) in Tunisia. Afr. Entomol. 2013, 21, 165-167. [CrossRef]

53. Gapon, D.A. First record of Leptoglossus occidentalis (Heteroptera: Coreidae) in Morocco. Heteropterus Rev. Entomol. 2015, 15, 161-163.

54. van der Heyden, T. Leptoglossus occidentalis Heidemann, 1910 (Hemiptera: Heteroptera: Coreidae: Coreinae: Anisoscelini) has reached the Greek island of Crete. Arq. Entomolóxicos 2017, 18, 185-187.

55. van der Heyden, T. First record of Leptoglossus occidentalis Heidemann, 1910 (Hemiptera: Heteroptera: Coreidae: Coreinae: Anisoscelini) in the Golan Heights. Rev. Gaditana Entomol. 2018, 9, 1-3.

56. van der Heyden, T. Summarized data on the European distribution of Leptoglossus occidentalis Heidemann (Heteroptera: Coreidae: Coreinae: Anisoscelini). Rev. Chil. Entomol. 2019, 45, 499-502. [CrossRef]

57. van der Heyden, T. First record of Leptoglossus occidentalis Heidemann, 1910 (Heteroptera: Coreidae: Coreinae: Anisoscelini) in Algeria. Rev. Gaditana Entomol. 2019, 10, 159-161.

58. van der Heyden, T.; Zettel, H. First record of Leptoglossus occidentalis Heidemann, 1910 (Heteroptera: Coreidae) from Cyprus. Z. Arb. Osterr. Entomol. 2019, 71, 177-178.

59. van der Heyden, T. First records of Leptoglossus occidentalis Heidemann (Heteroptera: Coreidae: Coreinae: Anisoscelini) in Finland. Rev. Chil. Entomol. 2020, 46, 73-74.

60. van der Heyden, T. First record of Leptoglossus occidentalis Heidemann, 1910 (Hemiptera: Coreidae) in Andorra. Arq. Entomolóxicos 2020, 22, 377-378.

61. van der Heyden, T. First record of Leptoglossus occidentalis Heidemann, 1910 in Guatemala (Hemiptera, Heteroptera, Coreidae). Bol. Asoc. Esp. de Entomol. 2020, 44, 213-214.

62. van der Heyden, T.; Faúndez, E. First records of Leptoglossus occidentalis Heidemann, 1910 (Hemiptera: Heteroptera: Coreidae) in Brazil and South Africa. Boletín Mus. Nac. Hist. Nat. Parag. 2020, 24, 28-30.

63. van der Heyden, T. First records of Leptoglossus occidentalis Heidemann, 1910 (Hemiptera: Heteroptera: Coreidae) in Estonia and Belarus. Heteroptera Pol. Acta Faun. 2021, 15, 5-6.

64. Team, R.C. R: A Language and Environment for Statistical computing; R Foundation for Statistical Computing: Vienna, Austria, 2008; ISBN 3-900051-07-0.

65. RStudio. Available online: http://www.rstudio.com (accessed on 10 June 2020).

66. Wickham, H. ggplot2: Elegant Graphics for Data Analysis; Springer-Verlag: New York, NY, USA, 2016; ISBN 978-3-319-24277-4. Available online: http:/ /ggplot2.tidyverse.org (accessed on 10 June 2020).

67. Delignette-Muller, M.L.; Dutang, C. fitdistrplus: An R Package for Fitting Distributions. J. Stat. Softw. 2015, 64, 1-34. [CrossRef] 
68. Peruzzi, A.; Cherubini, P.; Gorreri, L.; Cavalli, S. Le pinete e la produzione dei pinoli dal passato ai giorni nostri, nel territorio del parco di Migliarino, S. Rossore, Massaciuccoli; Pisa: Ento Parco Regionale Migliarino, San rossore, Massaciuccoli, 1998; 134p.

69. Calama, R.; Gordo, J.; Conde, M.; Madrigal, G.; Mutke, S.; Pardos, M.; Garriga, E.; Montero, G.; Finat, L.; Martín, R.; et al. Pérdidas de rendimiento de piña y piñón en las masas de Pinus pinea. Jorn. Presentación Proy. PROPINEA 2014, $21,2014$.

70. Loewe-Muñoz, V.; Balzarini, M.; Delard, C.; Álvarez, A. Variability of stone pine (Pinus pinea L.) fruit traits impacting pine nut yield. Ann. For. Sci. 2019, 76, 37. [CrossRef]

71. Calama, R.; Gordo, J.; Mutke, S.; Conde, M.; Madrigal, G.; Garriga, E.; Arias, M.; Pique, M.; Gandía, R.; Montero, G.; et al. Decline in commercial pine nut and kernel yield in Mediterranean stone pine (Pinus pinea L.) in Spain. iForest-Biogeosciences For. 2020, 13, 251-260. [CrossRef]

72. Blatt, S.E.; Borden, J.H. Distribution and impact of Leptoglossus occidentalis Heidemann (Hemiptera: Coreidae) in seed orchards in British Columbia. Can. Entomol. 1996, 128, 1065-1076. [CrossRef]

73. Bates, S.L.; Lait, C.G.; Borden, J.H.; Kermode, A.R. Effect of feeding by the western conifer seed bug, Leptoglossus occidentalis, on the major storage reserves of developing seeds and on seedling vigor of Douglas-fir. Tree Physiol. 2001, 21, 481-487. [CrossRef] [PubMed]

74. Bates, S.L.; Borden, J.H. Life table for Leptoglossus occidentalis Heidemann (Heteroptera: Coreidae) and prediction of damage in lodgepole pine seed orchards. Agric. For. Entomol. 2005, 7, 145-151. [CrossRef]

75. Forcella, F. Ovulate cone production in pinyon: Negative exponential relationship with late summer temperature. Ecology 1981, 62, 488-491. [CrossRef]

76. Redmond, M.D.; Forcella, F.; Barger, N.N. Declines in pinyon pine cone production associated with regional warming. Ecosphere 2012, 3, 1-14. [CrossRef]

77. Walther, G.R.; Roques, A.; Hulme, P.E.; Sykes, M.T.; Pysek, P.; Kuhn, I.; Zobel, M.; Bacher, S.; Botta-Dukat, Z.; Bugmann, H.; et al. Alien species in a warmer world: Risks and opportunities. Trends Ecol. Evol. 2009, 24, 686-693. [CrossRef]

78. Loewe-Muñoz, V.; Balzarini, M.; Álvarez-Contreras, A.; Delard-Rodríguez, C.; Navarro-Cerrillo, R.M. Fruit productivity of Stone pine (Pinus pinea L.) along a climatic gradient in Chile. Agric. For. Meteorol. 2016, 223, 203-216. [CrossRef]

79. Schröder, W.; Schmidt, G.; Schönrock, S. Modelling and mapping of plant phenological stages as bio-meteorological indicators for climate change. Environ. Sci. Eur. 2014, 26, 5. [CrossRef] 